\title{
HEATHER GREEN
}

University of Alberta

\section{The Rise of Motherhood: Maternal Feminism and Health in the Rural Prairie Provinces, 1900-1930}

While always an essential aspect of frontier life, the concept of Motherhood gained increased importance in Canada from 1900 to 1930. During this period, the Canadian nation experienced increasing pressures as the British-Canadian birthrate declined, the immigrant population grew, and the Great War claimed the lives of many of the nation's men. The Canadian state turned to women of British background to act as the saviours of the race, specifically through their position as mothers. This paper examines the conditions in which the Mothers of the Nation ideology arose, including demographic shifts, fear of 'race degeneration', and imperial values. ${ }^{1}$ This emerging concept of political motherhood was paralleled by the emergence of scientific motherhood. Promoted by the state in the form of the Department of Health Blue Books series, and largely informed by the eugenics movement, scientific motherhood was a method of applying biological principles to the betterment of the race through upholding the health of both infants and mothers. ${ }^{2}$ The state and society at large declared that white women had a duty and responsibility to their nation and to their race to repopulate the British breed.

Maternal feminists- a particular group of white, Anglo-Protestant, middle-class women, and male supporters, whose political ideologies were very much in keeping with the racial and class based hierarchical value system of the time - adopted the rhetoric of Mothers of the Nation to further their claims in the public discourse of

\footnotetext{
${ }^{1}$ Mothers of the Nation was a term used in political rhetoric between 1900 to 1930 to encourage white, British, middle-class women to reproduce and increase the population of British-Canadians. The idealization of motherhood was linked to the cult of domesticity which saw women in the domestic realm as natural nurturers and homemakers. Cynthia Comacchio, The Infinite Bonds of Family: Domesticity in Canada 1850-1940 (Toronto: University of Toronto Press, 1999).

${ }^{2}$ The Blue Books were a series of pamphlets printed by the Department of Health and distributed to families across Canada between 1921 and 1928. The topics of the Blue Books ranged from health, to proper domestic cleanliness, to motherhood advice.
} 
national responsibilities and rights to gain political power using the concept of motherhood. ${ }^{3}$

Furthermore, maternal feminism was a departure from radical feminism, which lacked support in most of Canada at this time. ${ }^{4}$ Maternal feminists gained much support from the general public through the conservative ideology of maternal feminism. Using the Grain Growers' Guide as a source to examine middleclass Prairie women's responses to the Mothers of the Nation ideology, the Blue Books, and scientific motherhood, it is clear that within the Mothers of the Nation rhetoric women used the language of race betterment and moral reform to advocate for adequate medical and health services in rural areas. What is clear through a study of these issues is that the concept of motherhood became a political category of nation-building in the early $20^{\text {th }}$ century, promoted by the state, and adopted by maternal feminists to gain support from opponents of radical feminism in their advocacy for advancements in both political and domestic spheres of life in the rural Prairie West.

\section{Immigration and Race in the Prairie West}

Prior to the $20^{\text {th }}$ century, motherhood and reproduction belonged to the natural and private spheres of life in which women were the experts and the state showed little concern. However, a combination of demographic shifts, a declining birth rate, and population loss due to the First World War changed the way that both the Canadian state and Canadian citizens thought about national development. While race degeneration was feared prior to the Great War, the population loss

\footnotetext{
${ }^{3}$ Maternal feminism was an ideology many feminists in the late $19^{\text {th }}$ century and early $20^{\text {th }}$ century used to further their political and domestic goals. Maternal feminism was rooted in domesticity and motherhood and encouraged public and political participation of women as mothers. This form of feminism gained much support from both women and men, largely because it did not threaten the existing gender roles and societal norms as radical feminism did. Women were seen as moral guides for children and for the nation, especially so in areas like the Western frontier where men outnumbered women and women's influence was highly regarded as a "civilizing" factor is overtly "manly spaces" (Barbara Jean Nicholson,_Feminism of the Prairie Provinces to 1916, MA thesis (Calgary: University of Calgary, 1976) 44. Maternal feminists were preoccupied with suffrage, temperance, and moral reform. They did not see any contradiction in their political aims and traditional, domestic roles. However, maternal feminists were highly criticized by more radical feminists for being too conservative and upholding patriarchal and oppressive structures.

${ }^{4}$ Discussed in more detail later in this paper, radical feminism refers to a specific group of feminist in the early $20^{\text {th }}$ century who opposed child-rearing, women in domestic roles, and upholding the status quo.
} 
experienced during the war years heightened the fear and intensified the state's response. ${ }^{5}$ These heightened fears maintained an earlier outlook concerned with the 'fabric of the race' (referring to British-Canada heritage), developed through the ideological lens of race, class, gender, and population growth. The political elite of the nation were those of British background. White, Anglo-Protestant, and middleor upper-class signified privilege in the beginning decades of the $20^{\text {th }}$ century.

However, race and class were not the only markers of privilege. Gender was an important distinction as well; the males of the British-Canadian elite dominated politics, business, law, and education whereas women, even those of BritishCanadian background, operated largely in domestic spheres. ${ }^{6}$ Arguably, this BritishCanadian dominance was most pronounced, and most threatened, in the Canadian west due to the racial and ethnic demographics of the settlement period. ${ }^{7}$

Racial and ethnic diversity marked the settling of the Canadian west. Four million people immigrated to Canada between 1891 and 1921. A high percentage of these came to the western provinces, though it is difficult to provide an exact count. However, the west received the most diversity in immigrant populations. ${ }^{8}$ Settling the Canadian west, as advertised in British immigration magazines such as the Imperial Colonist, was an opportunity to build the last white frontier. Historian Cecily Devereux argued that the Canadian west would "serve the British empire as a location for the generation of a new and stronger community of Anglo[Protestants]." 9 However, the demographic reality of the west did not match the recruitment rhetoric. During the early settlement years, though desiring to keep the frontier mainly British, the state was not totally strict about where those immigrating to the frontier came from. Canada's pre-First World War immigration

\footnotetext{
${ }^{5}$ Race degeneration was a popular concept during the late $19^{\text {th }}$ and early $20^{\text {th }}$ centuries. Both moral reformers and scientists believed that civilization was threatened by the biological changes in humans, often resulting from interracial reproduction. Many feared that the hierarchy of human races was in decline due to these social and biological changes in society.

${ }^{6}$ Sarah Carter, "Daughters of British Blood" or "Hordes of Men of Alien Race": The Homesteads-forWomen Campaign in Western Canada” in Great Plains Quarterly 29.4 (Fall 2009): 277.

${ }^{7}$ At this time, the West experienced more recent immigration, larger populations, and more diversity than in the eastern and central Canadian regions.

${ }^{8}$ Donald Avery, Reluctant Host: Canada's Response to Immigrant Workers, 1896-1994 (Toronto:

McClelland \& Stewart, 1995).

${ }^{9}$ Cecily Devereux, Growing a Race: Nellie L. McClung and the Fiction of Eugenic Feminism (Montreal:

McGill-Queen’s University Press, 2005) 54.
}

Past Imperfect Vol. XX 
policy centered on giving businessmen a free hand in recruiting labourers - who were willing to take low paying jobs that others would not - and in recruiting agriculturalists to settle the west. ${ }^{10}$ Restrictions placed on immigration mainly applied to immigrants' willingness and ability to fit into Canadian economic priorities. ${ }^{11}$ Historian Nadine Kozak explained, "By the 1920s, several ethnic groups were present on the rural Prairies, including Icelanders, French Canadians, Hungarians, Scandinavians, Jews, Brits, Germans, Ukrainians, Mennonites, Doukhobors, and Hutterites." ${ }^{2}$ At this time, however, the frontier was settled and Canada's claim on the west was secured by the time Alberta and Saskatchewan joined Confederation in 1905. The state's desire to maintain Britishness became threatened by the influx of immigrants in the west, while at the same time, many Canadians were lured south of the border seeking advanced economic opportunities, upsetting the British to immigrant ratio in Canada. ${ }^{13}$

Furthermore, the nation-wide birth rate of Canadian babies of British ancestry continued to decline since 1881 while the immigrant birth rate increased leading to a widespread fear that the rising immigrant population would outnumber British-Canadians. ${ }^{14}$ Many politicians and nationalists feared that this, in turn, would cause social degeneration and race suicide overthrowing the very fabric of the Canadian value system (specifically, social purity). ${ }^{15}$ The death toll of the First World War fed this fear with 60,661 deaths from a population of 8,148,000. ${ }^{16}$ The loss (or sacrifice) of so many 'fathers of the race' increased the importance of British re-population. ${ }^{17}$ Perhaps surprisingly, the state believed the solution to the problem of the diminishing national race could be found within the confines of the female, or

\footnotetext{
10 Avery, 23.

${ }^{11}$ Ibid.

${ }_{12}$ Nadine Kozak, "Advice Ideals and Rural Prairie Realities: National and Prairie Scientific Motherhood Advice, 1920-29" in Unsettled Pasts: Reconceiving the West through Women's History, ed. Sarah Carter (Calgary: University of Calgary Press, 2005): 188.

13 Angus McLaren, Our Own Master Race: Eugenics in Canada, 1885-1945 (Toronto: Oxford

University Press, 1990) 46.

${ }^{14}$ Cynthia Comacchio, The Infinite Bonds of Family: Domesticity in Canada 1850-1940 (Toronto: University of Toronto Press, 1999) 48.

${ }^{15}$ On social purity, see Mariana Valverde, The Age of Light Soap, and Water: Moral Reform in English Canada (Toronto: University of Toronto Press, 1991).

${ }^{16}$ Nadine Kozak, "Advice Ideals and Rural Prairie Realities: National and Prairie Scientific

Motherhood Advice, 1920-29," 188.

${ }_{17}$ Comacchio, 91.
} 
womanly, world. Because most non-white immigrants settled in the west there was increased pressure on white, middle-class women in the Prairies to uphold the British-Canadian race though reproduction. Beginning in the first decade of the 1900s, national rhetoric declared it was women's duty to their country to bear children as Mothers of the Nation. ${ }^{18}$

\section{Maternal Feminists and Mothers of the Nations}

Mothers of the Nation ideology was not isolated within Canada but was part of an international ideology with connections to the United States and Britain. ${ }^{19}$ In fact, in the early $20^{\text {th }}$ century most Canadian institutions and ideologies were rooted in British heritage and the desire to maintain Canada as a replica of the Motherland was conceived in imperial discourse as well. Late Victorian values and standards emigrated along with people to North America, creating "imperialist discourses of race regeneration, social purity, and imperial renewal."20 The Mothers of the Nation ideology is impossible to isolate from the eugenics movement, another movement at this time which focused on racial and social purity. ${ }^{21}$

The eugenics movement was a scientific approach to reproduction and improvement of the genetic composition of a population by increasing the reproduction of people with favorable genetic traits and decreasing the reproduction of those with undesirable traits. Eugenics was popular in both Canada and Britain during the early $20^{\text {th }}$ century. ${ }^{22}$ In Canada, the undesirables were the populations of immigrants, ethnic groups, and working-class who continued to produce high birth rates while the white, British, middle-class birth rate continued to decline. In the 1920s, eugenics was believed by its supporters to be "the idea of improving the

\footnotetext{
18 Angus McLaren and Arlene Tigar McLaren, The Bedroom and the State: The Changing Practises and Politics of Contraception and Abortion in Canada, 1880-1997 (Toronto: Oxford University Press, 1997) 68.

19 The New York Times published an article in 1910 entitled "Congratulates Mothers on "Anti-race" Suicide Accomplishment" when four white babies were born that week at one hospital.

"Congratulates Mothers on "anti-race" Suicide Accomplishment," in The New York Times, October 13, 1910.

${ }^{20}$ Cecily Devereux, "New Woman, New World: Maternal Feminism and the New Imperialism in the White Settler Colonies," in Women's Studies International Forum 22,2 (1999) 176.

${ }^{21}$ See Ann Taylor Allen, Feminism and Motherhood in Western Europe, 1890-1970: The Maternal Dilemma (New York: Palgrave Macmillan, 2005).

${ }^{22}$ Comacchio, 131.
} 
health of children by medical inspections, preventing the entry into the country of diseased aliens, and prohibiting the marriages of couples who were believed likely to produce defective offspring." 23

Motherhood as a new political category did not apply to all women. The ideology of Mothers of the Nation applied most to a specific group consisting of the existing privileges of being a white, British or British-Canadian, Anglo-Protestant and, middle- to upper-class woman. These women-as-mothers received an elevated importance in society, because mothers raised the future political leaders and the next generation of mothers. They upheld the Anglo-Protestant civilization through childbearing and rearing. The Grain Growers' Guide, the left-leaning organ of the United Grain Growers' Association and the most circulated farm paper in the Prairie Provinces, advocated in 1913 that, "a nation rises no higher than its mothers."24

Maternalism was the main strategy for regeneration giving women more significant national responsibilities. ${ }^{25}$ Maternal feminists, a group of feminists who emerged in the late $19^{\text {th }}$ century whose ideology was rooted in domesticity and motherhood, took this newfound responsibility as a way to further their cause. Women justified their claims to political and social rights by referencing their maternal role, arguing that to best provide for the children which they bear for the nation they ought to be awarded equality in the political arena, for only mothers know the best legislation for the well-being of children. ${ }^{26}$ Health improvements for both mother and child were the most commonly cited reform desire from rural Prairie feminists.

The emergence of Mothers of the Nation did not begin feminists' arguments for political rights and domestic reform. Instead, it gave feminists a language in

\footnotetext{
${ }^{23}$ Angus McLaren, “Keep Your Seats and Face Facts’: Western Canadian Women’s Discussion of Birth Control in the 1920s," in Canadian Bulletin of Medical History/Bulletin canadien d'histoire de la médecine 8,2 (1991): 191.

24 The Grain Growers' Guide, May 21, 1913, p.10. Nellie McClung expressed a similar statement in her In Times Like These, stating, "[ $[\mathrm{T}]$ he race can rise no higher than its women." Nellie McClung, In Times Like These (London: Appleton and Co., 1915) 97.

${ }^{25}$ Dominic Alessio, "Domesticating 'The Heart of the Wild': Female Personifications of the Colonies, 1886-1940” in Women's History Review 6.2 (1997) 265.

${ }^{26}$ Mariana Valverde, "'When the Mother of the Race Is Free': Race, Reproduction, and Sexuality in First-Wave Feminism." Gender Conflicts: New Essay's in Women's History, eds. Franca Iacovetta and Mariana Valverde (Toronto: University of Toronto Press, 1992) 3.
} 
which to frame their arguments upon entering a national discourse. Maternal feminists appealed to the public for support by highlighting the sacrifice women made for the nation and how little they got in return. The following passage, written by a Mrs. Marshall and read to the Quarterly Meeting of the Young Women's Christian Association printed February 27th, 1909 in The Edmonton

Bulletin, is representative of these types of appeals: The young bride feels that this [domesticity] is her world: this her God-given sphere. A narrow square it seems. Hemmed in by four square walls, with no voice in politics, shut out even from her church congress, and yet with a heart as loyal and true to her country, and a mind as quick and keen as her brother-man. ${ }^{27}$

While such passages are found scattered among newspaper sources across the west, The Grain Growers' Guide is a more thorough source to examine Prairie women's thoughts. Active between 1908 and 1928, The Grain Growers' Guide encouraged readers to write in and participate in discussion on politics and current affairs. ${ }^{28}$ It included a women's page, and later a longer women's section. Some of the women's

\footnotetext{
${ }^{27}$ Mrs. Marshall's paper was an essay read to the Quarterly Meeting of the Young Women's Christian Association. "The Narrow Sphere," in The Edmonton Bulletin, February 27, 1909, p.7. 28 The Grain Growers' Guide was in print from 1908-1928 and some of its female editors included Nellie McClung, Irene Parlby, and Isobelle Graham, and Francis Beynon. The Grain Growers' Guide provided commentary on politics, co-operative developments, agriculture techniques and equipment, and animal husbandry. In it's first year in print it devoted one page to women's suffrage, homestead, and dower law issues. After a few years, the women's page extended into a women's section which covered a range of topics from suffrage, to wage work, to household chores. The readership of The Grain Growers' Guide was mostly Western, farming families and labourers. It was the most widely distributed paper in Western Canada in the 1910s and 1920s. For more, see Barbara E. Kelcey and Angela E. Davis, eds. A Great Movement Underway: Women and the Grain Growers' Guide, 1908-1928: Selected Letters and Editorials from the Woman's Page (Winnipeg: The Manitoba Record Society, 1997). The Guide is an excellent source to analyze women's public discourse, women's issues, concerns, and responses to events and ideas in society. However, there are certain limitations to using news print as a foundational source. First, there is the issue of audience. The Guide's intended readership was farmers and labourers, however, in the West farmers and labourers consisted of many different racial and ethnic groups, many of which would have not spoken, or read, English and therefore, are not accounted for in the Guide's readership. Furthermore, education is a limitation in that people not literate would not have read, or written to, the paper. Selectivity is another limitation in that it is impossible to know how many people wrote into the paper solely based on printed letters to the editor, because the editor's may have selected certain letters to print and others to ignore. Finally, class and financial ability to subscribe to the paper is another factor to consider. Whatever the limitations, The Guide does prove to be a useful source to examine the ideas and responses of educated, literate, English-speaking, middle-class women and men in the Western provinces. This specific group consisted of the same demographic of maternal feminists and women who the Mother of the Nation ideology was targeted at, therefore, making The Guide a necessary source in my analysis.
} 
section editors included noted feminists such as Nellie McClung, Irene Parlby, Isobelle Graham, and Francis Marion Beynon. The editors of the Guide encouraged anyone to write and submit letters and editorials, including farm women of both labouring and middle classes. Common topics that women wrote in about included suffrage, marriage, eugenics, motherhood, and race regeneration. ${ }^{29}$

In many letters published in the Guide, women argued that the pressure placed on them to regenerate the British-Canadian race should warrant them greater rights in the political realm. For example, one editorial in the women's section of the Guide published in 1911 capitalized on the concept of motherhood to further the political desires of suffrage for the Prairies. Identifying herself as "An Interested Reader," the author argues:

I smile when I read the glib speeches of our politicians, in which they speak of the "Honor of Motherhood," etc., and yet will not allow us the franchise, the only power by which we can hope to improve the conditions under which our children will have to live. ${ }^{30}$

Maternal feminists also claimed that what they asked for was neither radical nor selfish, as they were simply upholding the argument made by the mainstream that safeguarding mothers is to safeguard the future, as the following passage from The Grain Growers' Guide in 1919 illustrates:

It must be clear, then, that we are not claiming anything for wives, or anything for women, but only for mothers, as mothers, and our claim so far is evidently none other than the claim already granted in principle that the next generation is entitled to due nurture. ${ }^{31}$

However, these types of arguments were not supported by all and were especially criticized by radical feminists.

Radical first-wave feminism focused on, and denounced, the inherent inequalities of the patriarchal structure of society. Radical feminists, who aimed to

${ }^{29}$ Copies of The Grain Growers' Guide are only digitized from 1909 to 1919, limiting the author's ability to examine the women's section into the 1920 s.

30 The Grain Growers' Guide, December 6, 1911 , p.57.

31 "The Safeguarding of Mothers Means the Guardianship of the Future," in The Grain Growers'

Guide, February 28 1919, p.27. 
challenge patriarchy by opposing strict gender roles and rejecting the practises of marriage and child rearing, asserted that those maternal feminists demanding rights based on a Mothers of the Nation argument were not real feminists because real feminists wanted enfranchisement for its own sake, because equality was an innate right owed to women and they should not have to provide a reason for it. ${ }^{32}$ Maternal feminists' voices were strongest after the Great War with the emergence of Mothers of the Nation ideology, whereas radical feminists separated themselves from child rearing in an effort to assert their autonomy and to participate in malecentered spheres. ${ }^{33}$

Feminist historian Ann Heilmann wrote about Mona Caird, a British first wave feminist critical of marriage and motherhood, who claimed motherhood was no more than "an oppressive patriarchal institution" and a cycle of women's bondage passed on to each generation. ${ }^{34}$ It was reported in MacLeod Times in 1927 that a British national conference of labour women which "went on record to the effect that motherhood is "the last relic of slavery." Mothers, attest the lady delegates, receive no wages for their work." ${ }^{35}$ Even into the 1970s, maternal feminists of the first wave were criticized by second wave feminists who condemned maternal feminism as too limiting and conservative. They argued that maternal feminists "only took the position of maternalism because it enabled them to articulate and perform the kind of gynocentric agency that the New Woman represented but had not been able to

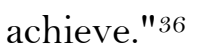

\footnotetext{
${ }^{32}$ Devereux, Growing a Race, 25.

${ }^{33}$ Allen, Feminism and Motherhood in Western Europe, 1890-1970, 67.

${ }^{34}$ Ann Heilmann, "Mona Caird (1854-1932): Wild Woman, New Woman, and Early Radical Feminist Critic of Marriage and Motherhood," in Women's History Review 5,1 (1996) 69-71. ${ }^{35}$ MacLeod Times, June 2, 1927 p. 2. Here it is important to note that the Canadian feminist movement did not begin in Canada, but was influenced internationally, especially by Britain and ideas crossed borders into the United States as well.

${ }^{36}$ The New Woman was a feminist ideal in which women were educated, politically active, independent, single, sexually explorative, and career-driven working largely for wages in industrial jobs and living in urban areas or cities. The New Women, as a term, appeared in the United States. Though this exact term was not used in Canada, I use the term throughout this paper to refer to the radical feminists who held the same ideologies and goals as the New Woman (Devereux, Growing a Race, 25). See also Adrienne Rich, OfWoman Born: Motherhood as Experience and Institution (New York: WW Norton and Company, 1976) which argues that there are two meanings of motherhood - one is a relational concept focused on the potential relationship between mother and child, and the power of reproduction. The second concept is the institution of motherhood aimed at ensuring that women remain under male control.
} 
While maternal feminists did not attempt to create a new gender order in society, as the radical feminists wanted, it was the lack of support for, and fear of, the idea of the New Woman which enabled Mothers of the Nation to gather mass support and further their cause. The term New Woman emerged in the 1880 s in the United States. Though it seems the term was not used in Canada, the ideas that it encompassed certainly existed in radical feminist thought within Canada. The New Woman "sought emancipation from gender-based restrictions" including the vote, education, and choice in sexual life, work, and social activities. In Growing a Race, Cecily Devereux argues, “[the New Woman's] actions, at least as they were configured in contemporary fictional and journalistic representations, were understood to be opposed to motherhood as a defining characteristic of femininity and as a "natural" constraint upon activity and mobility." 37 The declining British birthrate coupled with the view that feminists were against childbearing led to the understanding that the New Woman was a social hazard, not only in Canada, but to the British Empire worldwide. At the turn of the $20^{\text {th }}$ century imperial nationalists argued that women were the weaker sex and had little to offer a developing society other than their roles as mothers. ${ }^{38}$ Therefore, if the New Woman became the norm for women, society would face collapse. Deveraux further explains, "it is clear that she did serve as a focus for antifeminist sentiment precisely because, like the prostitute, she appeared to endanger the strength and security of the Anglo[Protestant] race. The condition of "the race" was becoming an article of considerable anxiety for Britons throughout the Empire" and generated vehement arguments against women's suffrage from men and woman across the globe. ${ }^{39}$

Radical feminism and the New Woman were not widely supported in Britain, Canada, and or United States because it departed drastically from the standards and norms of society, including heterosexual relationships and marriage, child-rearing, and strict gender roles. Sir Alfred Wright, anti-feminist writer in Britain, published The Unexpurgated Case Against Woman Suffrage in 1913 arguing that, "The task which I undertake here is to show that the Woman's Suffrage Movement has no real

\footnotetext{
37 Devereux, Growing a Race, 22.

38 Ann Towns, “The Status of Women as a Standard of 'Civilization'," in European Journal of International Relations 15,4 (2009) 698.

39 Devereaux, “New Woman, New World,” 176.
} 
intellectual or moral sanction, and that there are very weighty reasons why the suffrage should not be conceded to women." 40 While he did not effectively carry out his task in articulating the "very weighty reasons" against suffrage, he did suggest that suffragists' motives did not come from public interest, but a desire from personal liberties, whether economic, political or social. His main argument was that women should not be emancipated because it would upset the traditional societal order. In both Canada and across the border into the United States, some women's groups vehemently opposed the suffragist movement. Historian Susan Marshall explains, "antisuffragists countered demands for women's enfranchisement by contending that political participation would coarsen the gentle female character and endanger the family, the bulwark of society." 41

Other arguments made against suffrage came from the fear that women would forgo childbearing and enter the workforce. ${ }^{42}$ One writer calling them-self Wolf Willow, wrote an editorial to the "Country Homemakers" page of The Grain Growers' Guide in 1913 arguing that they opposed suffrage because "[I] want children to be better cared for and a better race of men reared" and that women working for wages could not secure this. Francis Marion Beynon, editor of the women's page at this time, replied that children were better cared for by the voter than ever before. ${ }^{43}$ She looked to Colorado as an example where women voted for twenty years and developed a variety of services such as joint guardianship between mother and father, raising the age of sexual consent, establishing juvenile courts, sanctioning compulsory education, and passing child labour laws among other things. Beynon argued all these came about due to woman's involvement in politics. ${ }^{44}$

\footnotetext{
${ }^{40}$ Sir Almroth Wright, The Unexpurgated Case Against Woman Suffrage (London: Constable and Company Ltd., 1913) 1.

${ }^{41}$ Susan Marshall, Splintered Sisterhood: Gender and Class in the Campaign against Woman Suffrage (Madison: University of Wisconsin Press: 1997) 4.

${ }_{42}$ McLaren and McLaren, 68.

${ }^{43}$ Francis Marion Beynon is a well-known Canadian feminist, journalist, and novelist who worked as an editor for women's columns in the Grain Growers' Guide from 1912 to 1917. She published a semiautobiographical novel titled Aleta Day in 1919. Francis Marion Beynon, Aleta Day (London: C.W. Daniel, 1919).

44 “Country Homemakers,” in The Grain Growers' Guide, October 1, 1913, p.10.
} 
However, the feminist figure of Mother of the Nation replaced the New Woman ideology, detracting from the radical elements of feminism, and maintaining the existing sex roles. ${ }^{45}$ Feminist historian Carol Bacchi argues that the suffrage movement in Canada was successful due to its moderate character. ${ }^{46}$ Furthermore, like eugenicists and most suffrage groups, maternal feminists were largely middleclass, of Christian religion and they saw the power of motherhood according to class, racial, and ethnic divides. Their political desires were based on upholding the status quo of the race and they gained much support from those who previously opposed feminism. Maternal feminists also gained support from other feminist groups. After all, the New Woman and maternal feminists wanted the same things equal rights, suffrage, education, and social reform - it was only their approaches and ideologies behind their approaches that differed. ${ }^{47}$ It seems that many Canadians would have agreed when Francis Marion Beynon in The Grain Growers' Guide assured her readers that "the instinct for motherhood is primal, and professional work, university life even - even the ballots are not going to change it." 48

\section{The Campaign for Health and Medical Services}

Motherhood became a national topic. Prior to the fear of a declining race, motherhood and birth were natural, private spheres of life. With the advent of this fear, motherhood and birth became medicalized and shifted into the public sphere. ${ }^{49}$ The state took a particular interest in the advancement of the British population in promoting white, middle-class, Anglo-Protestant women and families to reproduce. However, the maternal feminist claim on motherhood went much further than simply repopulating the British breed. Feminists, using their heightened status in society, continued their campaign for improved infant and maternal health. ${ }^{50}$ The

\footnotetext{
${ }_{45}$ Carol Lee Bacchi, Liberation Deferred? The Ideas of the English-Canadian Suffragists, 1877-1918 (Toronto: University of Toronto Press, 1983) 24

46 Ibid., 3.

${ }^{47}$ Devereux, Growing a Race, 25.

48 "The Country Homemakers," in The Grain Growers' Guide October 1, 1913, p.10.

${ }^{49}$ Katherine Arnup, Education for Motherhood: Advice for Mothers in Twentieth-Century Canada (Toronto: University of Toronto Press, 1994).

${ }^{50}$ Diane Dodd, "Advice to Parents: The Blue Books, Helen MacMurchy, MD, and the Federal Department of Health," in Canadian Bulletin of Medical History/Bulletin canadien d'histoire de la médecine 8,2 (1991) 204.
} 
federal government established the Department of Health in 1919 and began distributing public health booklets to future and expecting mothers. These books were commonly called the Blue Books and were distributed nation-wide free of charge. Written by Helen MacMurchy, eugenicist and feminist, the Blue Books gave advice on everything from arranging doctor's visits to cooking for the family to keeping a clean home. The most popular of the Blue Books was The Canadian Mother's Book (1925), in which MacMurchy claimed "No national service is greater or better than the work of the Mother in her own home." 51

The Blue Books were the eugenics movement's most insidious tool. Eugenics was more than a scientific movement; it tied in with middle-class moral reform that was widely supported and promoted by maternal feminists. ${ }^{52}$ After WWI, eugenicists believed the problem of race degeneration was internal and required more than simply reproducing, but focused on racial improvement through education. ${ }^{53}$ The Canadian Mother's Book was considered the official advice booklet for Canadian mothers. The title of the book is important; when examining the content, it is clear that these books were produced with the intention of teaching immigrants how to be Canadian in parenting, cleaning, cooking and any other topics covered in these books. The Blue Books were not only intended to keep the British population well stocked, but they were also intended to teach the non-British population how to best maintain a house and family in a moral way. Aside from pregnancy and childcare, the Blue Books also targeted immigrant groups with pamphlets titled How We Cook in Canada and Beginning a Home in Canada. ${ }^{5+}$ The Department of Health had a very specific idea about the proper values of motherhood.

These publications intended to foster race betterment were in keeping with the ideas of the moral reform movement at this time with an emphasis on "light, soap, and water" by instructing readers how to keep their homes clean, effective

\footnotetext{
${ }^{51}$ Helen MacMurchy, The Canadian Mother's Book(Ottawa: Dominion of Canada Department of Health, 1925) 1.

52 Dodd, 209.

${ }^{53}$ Ibid.

${ }^{54}$ Helen MacMurchy, How to Make Our Canadian Home (Ottawa: Dominion of Canada Department of Health, 1927); How We Cook in Canada (1923).
} 
means of personal hygiene, clean air, and healthy food. ${ }^{55}$ Kozak argues that it is through the scientific motherhood campaign that class, race, gender, and ethnicity divided women, as Anglo-Protestant, middle-class women aimed to educate women they deemed inferior in the best practises of childrearing. This included indigenous, rural, and immigrant women. ${ }^{56}$ Women in the Prairie west did their duty, not only in bearing children, but also in practising social and moral reform in their communities. Rural women in the west experienced great isolation and times of loneliness in the Prairies. They started to meet for company, but soon after they began to organize to achieve feminist goals and promote social reform discussion and activities. ${ }^{57}$ Stephanie Simon argues that the issues rural Prairie feminists debated included "improvement for life, birth control, suffrage, equal rights, dower law, health care, and homesteading." 58 The Women's Grain Growers' Association in Saskatchewan organized as early as 1913, the United Farm Women of Alberta in 1915, and western branches of the Woman's Christian Temperance Union attempted to eliminate social ills such as alcoholism by promoting abstinence from alcohol to the Canadian and immigrant working class, lack of education among farming, labourer, and immigrant groups, and lack of health care in rural areas. ${ }^{59}$

In most regions in Canada, industrialization and urbanization meant more women were separated from traditional female networks and were likely to seek professional advice. ${ }^{60}$ In the west, the rural isolation from other women, or separation and distance from their own mothers, encouraged many women to seek the advice from experts. ${ }^{61}$ The Blue Books were the creation of an urban middle-class and though it was distributed nation-wide, it did not account for regional, or geographic, differences and had particular drawbacks for the western region. Dianne

\footnotetext{
${ }_{55}$ The Blue Books series consisted of How to Avoid Accidents and Give First Aid(1921), How We Cook in Canada (1923), How to Take Care of Mother (1923), How to Take Care of the Baby (1923), How to Take Care of the Children (1925), The Canadian Mother's Book (1925), How to Manage Housework in Canada (1926), How to Make Our Canadian Home (1927), Mother: A Little Book for Men (1928).

${ }^{56}$ Kozak, 202.

${ }^{57}$ Stephanie Simon, Women on the Canadian Prairies, Course Paper (Athabasca: Athabasca University, 2009) 20.

${ }^{58}$ Ibid.

${ }_{59}$ Wendy Mitchinson, Giving Birth in Canada, 1900-1950 (Toronto: University of Toronto Press, 2002) 151.

${ }^{60}$ Arnup, 7.

61 Ibid., 120
} 
Dodd and Nadine Kozak have published detailed studies of the impacts advice literature has had on childrearing practises in the west. ${ }^{2}$ However, there is little analysis of the ways in which rural maternal feminists responded to the Blue Books. Though the Blue Books were widely distributed, their advice was not always practical for western mothers. For example, The Canadian Mother's Book stressed the importance of seeking out a good doctor and practising frequent pre-natal care. This advice was not helpful to the majority of women in the rural Prairies, as they could not afford the cost of medical care or were too far away from doctors to visit often. The lack of trained medical practitioners and adequate household services such as running water and heat was another impediment on rural women's childbirth experiences. ${ }^{63}$ The lack of adequate health care was a major issue for rural feminists and was widely noted by the mass population of the western provinces. ${ }^{64}$ Feminists adopted the language of nation-building to express problems which the Blue Books made clear. If women were expected to reproduce physically and morally healthy babies, they needed adequate services to do so.

As Cynthia Comacchio argues, "The Prairie provinces were the metaphoric cradle of the nation, the specific site of intentional, planned, and carefully promoted nation-building."65 John A. Macdonald's vision for the west through the National Policy was as an agrarian hinterland for the central Canadian core. In essence, maternal feminists (and agrarian reformers) argued, the pioneer farmer was the "soul of the nation" upholding the rest of the nation, and farmer's wives were the true Mothers of the Nation. ${ }^{66}$ Furthermore, the west was the first proponent of eugenics and British Columbia and Alberta went the furthest in passing legislation to sterilize the feeble-minded at a time when the nation felt threatened by the unfit. ${ }^{67}$ Maternal feminists made a case that they went above and beyond their duty

\footnotetext{
${ }^{62}$ Nozak. Diane Dodd, "Advice to Parents: The Blue Books, Helen MacMurchy, MD, and the Federal Department of Health" in Canadian Bulletin of Medical History/Bulletin canadien d'histoire de la médecine 8,2 (1991): 203-230.

${ }^{63}$ Nanci Langford, "Childbirth on the Canadian Prairies, 1880-1930," in Telling Tales: Essays in Western Women's History eds. Catherine A. Cavanaugh and Randi R. Warne (Vancouver: UBC Press, 2000): 149.

64 Ibid., 147.

${ }^{65}$ Comacchio, 44.

${ }^{66}$ Ibid., 43. Howard Palmer and Tamara Palmer, Alberta, a New History (Edmonton: Hurtig, 1990) 237.

${ }_{67}$ McLaren, Our Own Master Race, 105.
} 
in reproducing a higher British population, decreasing the population of the unfit, and improving the character of undesirables by implementing practises of moral and social reform.

The Blue Books also did not account for rural Prairie women's daily experiences. Of necessity, women worked alongside their husbands farming and constructing homesteads. In fact, one of the most contested of feminist issues in the west was the homesteads for women campaign in which women advocated for the right to own and farm their own land. ${ }^{68}$ They realized that though they shared in the work, they were not treated as equals under the law or in settlement culture. ${ }^{69}$ However, a more immediate and dire issue was that of mortality. Many western newspapers contained pages such as “Mother's Number” and “Mother's Experiences" in The Grain Growers' Guide which contained columns and articles specifically about motherhood practises, concerns, and tips in the west. ${ }^{70}$ Women wrote in and editors of the page published articles about taking care of babies in isolated areas. One common reference in western papers that are not reflected in the Blue Books was women's need to work on the farm or the homestead during, and after, pregnancy. Mothers' pages stressed the importance of rest for new and expecting mothers, lessening the load of strenuous work, and proper nourishment. ${ }^{71}$ The Grain Growers' Guide advertised a booklet prepared by a Winnipeg doctor available for a cost of five cents to young and expecting mothers located far from doctors and nurses. ${ }^{72}$

Health care was an issue for Prairie women before the suffrage movement began in 1910 and remained an issue of great concern long after Prairie women gained the right to vote in 1916. ${ }^{73}$ The Woman's Hospital Aid Society was based in Calgary as early as 1889 and Regina women formed a group and raised funds to

\footnotetext{
${ }^{68}$ See Sarah Carter, "Daughters of British Blood" or "Hordes of Men of Alien Race": The Homesteads-for-Women Campaign in Western Canada," in Great Plains Quarterly 29.4 (Fall 2009): 267-286.

${ }^{69}$ Simon, 20.

${ }^{70}$ Prairie Farmer, "Woman's Suffrage and Women" July 11909 p11. Nothing specific to western, however underneath this is an article "Before the Baby Comes" advising women to eat healthy, natural foods (salads, fruits, veg) and exercise but do not over exert.

71 'Mother's Experiences,” in The Grain Growers' Guide, February 25, 1914.

72 The Grain Growers' Guide, July 9, 1913 p.3.

73 Palmer and Palmer, 177.
} 
build the Cottage Hospital at the turn of the century. ${ }^{74}$ The very survival of children, often taken for granted in urban areas, was frequently at risk in rural, Prairie settings. The Grain Growers' Guide published an article by E.A. Weir in 1916 titled "Better Doctoring thru Hospitals" which argued for the need of improved medical care and municipal hospitals in the Prairies:

We are constantly striving to secure immigrants from foreign countries, many of whom must be a burden for some time, and yet we have neglected to give even reasonable assistance in the conservation of the lives of men, women, and children of settlers already here and established. [... $]$ There is hardly a day that somewhere on the great, boundless and lonesome plains ... a man or women does not succumb to conditions and end up in one of the asylums. ${ }^{75}$

It is worth nothing that MacMurchy's Blue Books did not overlook fathers' roles in raising healthy children. Though the mother, it was assumed, held all responsibility for caring for the babies and children, the father was responsible to care for the mother. MacMurchy published Mother: A Little Bookfor Men in 1928 as a pamphlet for expecting fathers. In this pamphlet, she provides statistics on maternal mortality rates. 1,532 mothers died during childbirth or shortly after from July 1926 to July 1927. MacMurchy lists 347 lives lost because of poor medical care specifically, because the doctor not called until labor began, not called until the women was already dying, not called until days after birth, or no doctor present at birth. ${ }^{76} 406$ of these deaths were in the Prairie provinces, and it is reasonable to assume that most of them would have been rural Prairie women, where medical access was limited. ${ }^{77}$ In many cases, women helped construct the homes and farm the land. ${ }^{78}$ Even in factory jobs women's wages were considerably less than men's. ${ }^{79}$ Whether working on the farm or working in a factory, the concept of motherhood had become a professionalized category. One 1913 editor of "The Home” page in The

\footnotetext{
74. Barbara Jean Nicholson, Feminism of the Prairie Provinces to 1916, MA thesis, (Calgary: University of Calgary, 1976) 50.

75 "Better Doctoring thru Hospitals", The Grain Growers' Guide, November 1, 1916 p.19.

${ }^{76}$ Helen MacMurchy, Mother: A Little Book for Men (Ottawa: Dominion of Canada Department of Health, 1928) 13.

77 Ibid., 2.

${ }^{78}$ Simon, 5.

79 The Grain Growers' Guide, March 5, 1913, Page 1. On average, women receive 21.75 a month in factory work where men got 38.33 .
} 
Grain Growers' Guide, Mary Ford, advocated for the right of mothers based on biological, sociological, and eugenic principles. Ford argues "we now see that the expectant mother is in actual fact working, and that if we ask her to do any other kind of work, we are simply sacrificing the future to the present $[\ldots]$." 80 The article also highlights that mothers' work, and therefore rights, extend beyond the pregnancy stage into infancy and child stage as well and that husbands can help their wives by providing labour saving technologies and hygienic services such as running water, which were lacking in many Prairie homes. ${ }^{81}$ The Grain Growers' Guide published full page advertisements for McClary's Kootenay stove range and Hoosier's Cabinets which claimed the cabinets would "save hours of time" and "cut kitchen time in half." ${ }^{2}$ The ad declared that exhausting kitchen work "robs women of health." 83

Western women worked just as hard as men and struggled to survive child birth due to a lack of medical services. Furthermore, as one feminist argued, on the Prairies "babies die in horrible numbers because the everlasting principle of the Rights of Mothers is not granted amongst us." ${ }^{84}$ Of course, there were organizations such as the Red Cross and the Victorian Order of Nurses where Prairie women could seek pre-natal care, but these voluntary organizations did not have the same expertise, medical training, and medical equipment available to them as a hospital had. ${ }^{85}$ The Grain Growers' Guide published a front page article in 1912 titled "The War on Women” which argued that "brave women living on western Prairies, bearing the cross of motherhood without proper care and giving the best of their lives in the struggle to win a corner of the earth which they and their families may call home." The author goes on to argue that protective tariffs, extortionate freight rates and interest charges are keeping women back. ${ }^{86}$ Mary Ford captured

\footnotetext{
80 “The Home,” in The Grain Growers' Guide, March 6, 1912 p.35.

81 Veronica Strong-Boag, "Pulling a Double Harness or Hauling a Double Load: Women, Work, and Feminism on the Canadian Prairies," in The Prairie West; Historical Readings, 2nd ed. ed r. Douglas Francis and Howard Palmer (Edmonton: Pica Press, 1992) 406. See also Nancie Langford, "Childbirth on the Canadian Prairies, 1880-1930," 147.

82 The Grain Growers' Guide, August 2, 1916, p.25. The Grain Growers' Guide, December 6, 1916 p.55.

83 The Grain Growers' Guide, December 6, 1916 p.55.

84. "The Safeguarding of Mothers Means the Guardianship of the Future," in The Grain Growers'

Guide, February 28, 1919, p.27.

${ }^{85}$ Kozak, 192.

86 The Grain Growers' Guide, November 271912 p.1.
} 
this connection between Mothers of the Nation and western medical care in a Grain Growers' Guide article, stating, "the economic rights of mothers, as mothers, are therefore paramount $[\ldots .$.$] she created the future" and offered an appeal for "state$ obstetricians ... who shall protect and serve the nation's mothers, and keep them alive and well for future motherhood." 87

\section{Conclusion}

The specific medical advancements achieved as a direct result from Prairie maternal feminists' advocating is impossible to determine. What is clear, however, is that women on the Prairies noted the rising importance of motherhood in the $20^{\text {th }}$ century and harnessed it as a tool for both political advancements in gaining the right to vote and, perhaps more so in the west, in gathering support for social reform in the form of improved health services to the rural Prairie west. The shift from New Woman feminism to maternal feminism seemed to generate much more support from the masses. Many British-Canadians feared that New Woman feminism would cement their racial decline through entering the workforce and rejecting the practise of childbearing. Some radical feminists did encourage such ideologies and were quite critical of maternal feminism. However, maternal feminism was a comfort to most, as it did not threaten to alter the existing sex roles and it upheld the status quo through the repopulation of white, British, AngloProtestant, middle-class families. In the Prairies, specifically, health and welfare of children and mother were crucial to maintaining the work of farms and homesteads. The Blue Book campaign made it abundantly clear to mothers that though they were expected to bear the burden of Mothers of the Nation, Prairie women suffered illness and a mortality rate higher than elsewhere in the country. The views and opinions of maternal feminists and their supporters are documented in The Grain Growers' Guide in which editors and respondents published their responses and ideas about the motherhood debate. These public discussions of motherhood and feminism make clear that aside from gender, race, and class ideologies there was a crucial regional element at play that explains why certain causes were advocated in some

87 “The Home,” in The Grain Growers' Guide, March 6, 1912 p.35. 
areas more than others, how different types of feminism would gain support in a rural or urban setting, and how the feminist movement interacted with, and shaped, other contemporary political reform movements. The case of maternal feminism and Prairie regionalism lends itself well for future historical work. 


\section{Bibliography}

I) Primary Documents

a) Newspaper articles

The Edmonton Bulletin, "The Narrow Sphere," February 27, 1909, p.7.

The Grain Growers' Guide, "The Safeguarding of Mothers Means the Guardianship of the Future," February 28, 1919, p.27.

The Grain Growers' Guide, December 6, 1916 p.55.

The Grain Growers' Guide, "Better Doctoring thru Hospitals," November 1, 1916 p.19.

The Grain Growers' Guide, August 2, 1916, p.25.

The Grain Growers' Guide, "Mother's Experiences," February 25, 1914.

The Grain Growers' Guide, "The Country Homemakers," October 1 1913, p.10.

The Grain Growers' Guide, July 9, 1913 p.3.

The Grain Growers' Guide, May 21, 1913, p.10.

The Grain Growers' Guide, March 5, 1913, p.1.

The Grain Growers' Guide, November 27, 1912 p.1.

The Grain Growers' Guide, “The Home,” March 6, 1912, p.35.

The Grain Growers' Guide, December 6, 191 1, p.57.

MacLeod Times, June 2, 1927 p.2.

The New York Times, "Congratulates Mothers on "Anti-Race” Suicide

Accomplishment," October 13, 1910.

Prairie Farmer, "Woman's Suffrage and Women," July 1, 1909, p1 1.

Saturday News, "The Motherhood Instinct," August 20, 1910, p.8.

b) Published Primary Material

Kelcey, Barbara E. and Angela E Davis, eds. A Great Movement Underway: Women and the Grain Growers' Guide, 1908-1928: Selected Letters and Editorials from the Woman's Page. Winnipeg: The Manitoba Record Society, 1997.

MacMurchy, Helen. How to Avoid Accidents and Give First Aid. Ottawa: Dominion of Canada Department of Health, 1921.

. How We Cook in Canada. Ottawa: Dominion of Canada Department of Health, 1923.

. How to Take Care of Mother. Ottawa: Dominion of Canada Department of Health, 1923.

. How to Take Care of the Baby. Ottawa: Dominion of Canada Department of Health, 1923.

The Canadian Mother's Book. Ottawa: Dominion of Canada Department of Health, 1925.

. How to Take Care of the Children. Ottawa: Dominion of Canada Department of Health, 1925.

. How to Manage Housework in Canada. Ottawa: Dominion of Canada Department of Health, 1926.

. How to Make Our Canadian Home. Ottawa: Dominion of Canada Department of Health, 1927.

. Mother: A Little Book for Men. Ottawa: Dominion of Canada Department of

Health, 1928. 
McClung, Nellie. In Times Like These. London: Appleton and Co., 1915.

Wright, Sir Almroth. The Unexpurgated Case Against Woman Suffrage. London:

Constable and Company Ltd., 1913.

c) Theses/Research Papers

Nicholson, Barbara Jean. Feminism of the Prairie Provinces to 1916. MA thesis, Calgary: University of Calgary, 1976.

Simon, Stephanie Jayne. Women on the Canadian Prairies. Course Paper. Athabasca: Athabasca University, 2009.

II) Secondary Material

Alessio, Dominic David. "Domesticating 'the heart of the wild': Female

Personifications of the Colonies, 1886-1940.” Women's History Review 6.2 (1997): 239-270.

Allen, Ann Taylor. Feminism and Motherhood in Western Europe, 1890-1970: The

Maternal Dilemma. New York: Palgrave Macmillan, 2005.

Arnup, Katherine. Education for Motherhood: Advice for Mothers in Twentieth-Century

Canada. Toronto: University of Toronto Press, 1994.

Avery, Donald. Reluctant Host: Canada's Response to Immigrant Workers, 1896-1994.

Toronto: McClelland \& Stewart, 1995.

Bacchi, Carol Lee. Liberation Deferred? The Ideas of the English-Canadian Suffragists, 1877-1918. Toronto: University of Toronto Press, 1983.

Carter, Sarah. "Daughters of British Blood" or "Hordes of Men of Alien Race": The Homesteads-for-Women Campaign in Western Canada." Great Plains Quarterly 29.4 (Fall 2009): 267-286.

Comacchio, Cynthia. The Infinite Bonds of Family: Domesticity in Canada 1850-1940.

Toronto: University of Toronto Press, 1999.

Devereux, Cecily. Growing a Race: Nellie L. McClung and the Fiction of Eugenic

Feminism. Montreal: McGill-Queen’s University Press, 2005.

."New Woman, New World: Maternal Feminism and the New Imperialism

in the White Settler Colonies." Women's Studies International Forum 22.2

(1999): 175-184.

Dodd, Diane. "Advice to Parents: The Blue Books, Helen MacMurchy, MD, and the Federal Department of Health." Canadian Bulletin of Medical History/Bulletin canadien d'histoire de la médecine 8.2 (1991): 203-230.

Heilmann, Ann. "Mona Caird (1854-1932): Wild Woman, New Woman, and Early Radical Feminist Critic of Marriage and Motherhood." Women's History Review 5.1 (1996): 67-95.

Kozak, Nadine. "Advice Ideals and Rural Prairie Realities: National and Prairie Scientific Motherhood Advice, 1920-29." Unsettled Pasts: Reconceiving the West through Women's History. Ed. Sarah Carter. Calgary: University of Calgary Press, 2005. 179-204.

Langford, Nanci. "Childbirth on the Canadian Prairies, 1880-1930." Telling Tales:

Essays in Western Women's History. Eds. Catherine A. Cavanaugh and Randi R. Warne (Vancouver: UBC Press, 2000): 147-173.

Marshall, Susan. Splintered Sisterhood: Gender and Class in the Campaign against Woman Suffrage. Madison: University of Wisconsin Press: 1997. 
McLaren, Angus. “Keep Your Seats and Face Facts': Western Canadian Women’s Discussion of Birth Control in the 1920s." Canadian Bulletin of Medical History/Bulletin canadien d'histoire de la médecine 8.2 (1991): 189-202. . Our Own Master Race: Eugenics in Canada, 1885-1945. Toronto: Oxford University Press, 1990. and Arlene Tigar McLaren. The Bedroom and the State: The Changing Practises and Politics of Contraception and Abortion in Canada, 1880-1997. Toronto: Oxford University Press, 1997.

Mitchinson, Wendy. Giving Birth in Canada, 1900-1950. Toronto: University of Toronto Press, 2002.

Palmer, Howard and Tamara Palmer. Alberta, a New History. Edmonton: Hurtig, 1990.

Rich, Adrienne. Of Woman Born: Motherhood as Experience and Institution. New York: WW Norton and Company, 1976.

Strong-Boag, Veronica. "Pulling a Double Harness or Hauling a Double Load: Women, Work, and Feminism on the Canadian Prairies." The Prairie West; Historical Readings. 2nd ed. eds. Douglas Francis and Howard Palmer. Edmonton: Pica Press, 1992. 401-143.

Towns, Ann. "The Status of Women as a Standard of 'Civilization'.” European Journal of International Relations 15,4 (2009): 681-706.

Valverde, Mariana. The Age of Light Soap, and Water: Moral Reform in English Canada. Toronto: University of Toronto Press, 1991.

. "'When the Mother of the Race Is Free': Race, Reproduction, and Sexuality in First-Wave Feminism." Gender Conflicts: New Essay's in Women's History. Eds. Franca Iacovetta and Mariana Valverde. Toronto: University of Toronto Press, 1992. 3-27. 